American Journal of Biochemistry and Biotechnology 2 (3): 97-104, 2006

ISSN 1553-3468

(c) 2006 Science Publications

\title{
Control of Phenolic Compound Secretion and Effect of Growth Regulators for Organ Formation from Musa spp. cv. Kanthali Floral Bud Explants
}

\author{
Soubir Titov, Salil Kumar Bhowmik, Ajoy Mandal, Md. Sadrul Alam and Sarder Nasir Uddin \\ Biotechnology and Genetic Engineering Discipline, Khulna University, Khulna-9208, Bangladesh
}

\begin{abstract}
The study was undertaken to examine banana cv. Kanthali floral bud apex as an alternative source material for in vitro propagation because huge number of explants die due to microbial contamination in case of shoot tip explants. Contamination free cultures were established by treating the floral bud explants with $0.1 \% \mathrm{HgCl}_{2}$ for 6 min. This study found that inflorescence tissues of experimental plant was almost contamination free but was high in phenolic compounds. Phenolic compounds secretion was successfully stopped by pre-soaking them in an antioxidant solution of $0.125 \%$ potassium citrate: citrate. After antioxidant treatment the floral bud explants were cultured on MS medium supplemented with different concentrations and combinations of $\mathrm{BA}+\mathrm{Kn}+\mathrm{IAA} / \mathrm{IBA}+15 \% \mathrm{CW}$. Compact, white/greenish white callus was formed in different amount at all concentrations after 3 weeks of culture. All were again subcultured at same medium and after another $30-35$ days at $2.0 \mathrm{mg} \mathrm{L}^{-1} \mathrm{BA}+2.0 \mathrm{mg} \mathrm{L}^{-1} \mathrm{Kn}+2.0 \mathrm{mg} \mathrm{L}^{-1}$ IAA+15\%CW some callus showed embryogenic structure.
\end{abstract}

Key words: Musa spp. cv. Kanthali, floral bud apex, antioxidant, callus, somatic embryo

\section{INTRODUCTION}

Banana (Musa spp.) is the $4^{\text {th }}$ largest food crop in the world and affects lives of 400 million people ${ }^{[1]}$. It is a nutritious fruit rich in carbohydrates and a good source of vitamins. Musa spp. cv. Kanthali (genome $\mathrm{AAB}$ ) is a traditional table banana cultivar of Bangladesh $^{[2]}$. The plant is only found in the southern part of the country and its population is continuously decreasing due to lack of commercial cultivation. Its production rate is relatively lower but the plant is more salt tolerant and disease resistant than other commercial cultivars.

The development of micropropagation techniques has been a major focus of Musa research during the past two decades and such techniques have now been well established $^{[3,4]}$. Micropropagation of banana has been achieved using shoot tip $^{[5]}$ and from male floral apices $^{[6]}$. Meristem culture for clonal propagation and virus eradication was done by Gupta ${ }^{[7]}$. There are also reports of somatic embryogenesis and regeneration in liquid medium ${ }^{[8-10]}$. Utilization of whole flowers, buds, ovary sections and inflorescence sections as primary explant source material has been reported ${ }^{[11-13]}$. Bunn and Dixon ${ }^{[14]}$ demonstrated that adventitious shoot formation arises directly from the perianth or external ovary tissues in Blandfordia grandiflora, with this technique proving advantageous for rapid shoot regeneration with minimal explant material. This protocol is also useful for conservation of endangered species as it is a nondestructive method utilizing seasonal structures of the plant therefore allowing for the preservation of the mother plant ${ }^{[12]}$. This method of in vitro propagation demonstrates that many hundreds of clones can be obtained successfully from a single inflorescence of date palms ${ }^{[15]}$.

For in vitro propagation of banana, bacterial contamination is a great problem. Although initially surface sterilization works, later on microbial contamination at the base of the explant is observed within 7 to 15 days after inoculation. Bacterial growth is also observed around the explants in the culture media. Huge number of explants is destroyed in the culture due to endogenous bacteria ${ }^{[16]}$. In this aspect, utilization of immature inflorescence tissue as explant material can favors minimal contamination rates compared to other tissues. Another problem of in vitro cultured explants, accompanied by darkening of culture medium has been attributed to phenolic compounds exuded from tissues and accumulating in the culture medium. This process is initiated by browning of the surface of plant tissues due to the oxidation of phenolic compounds resulting in the formation of quinones which are highly reactive and toxic to plant tissue ${ }^{[17]}$. Understanding the processes contributing to the oxidation of phenols and how these can be minimized when initiating explants is critical for successful in vitro culture.

However, high productivity in agriculture output has been mainly achieved through breeding programs and genetic manipulation. Therefore, present investigation was carried out to establish in vitro rapid clonal propagation of Musa spp. cv. Kanthali from its floral bud apices. The aims of the experimental design addresses the following aspects of in vitro development are:

Corresponding Author: $\quad$ Soubir Titov, EX-15, Road No. 28, Nirala R/A, Khulna-9100, Bangladesh, Tel: +88-041-731563 
* That sterilization procedure can be developed which will optimize tissue survival in vitro.

* That antioxidant treatment minimizes phenolic exudation.

* That cytokinin and auxin ratios will facilitate tissue regeneration.

* That certain tissue types will respond to successful regeneration.

\section{MATERIALS AND METHODS}

Collection and preparation of explants: Banana cv. Kanthali (Genome AAB), a Cavendish type leading traditional cultivar of southern part of Bangladesh was the investigating subject. The source material used for culture establishment was banana floral bud explants. The plant materials were collected from a village named Amtola in Batiaghata Thana, Khulna and was very near from Khulna University campus.

Terminal floral apices of banana were collected from mature plants after they produced all possible hands. The terminal bud was cut from the peduncle and the bracts with their associated hands of male flowers were removed in a stepwise manner until they became too small to remove by hand. Working with a dissecting microscope, scalpel and forceps, the remaining bracts and minute hand of flowers were removed until the rounded growing point was exposed. The floral apex and approximately $1 \mathrm{~cm}$ long subtending peduncle tissue were excised.

Disinfection procedure: The surface sterilization procedure began with dissection of explant material into manageable units. Stem sections containing axillary buds and immature inflorescences were treated by initially removing the small leaflets and cleaning away surface detritus under running tap water for 1 to 2 min. A plastic vessel (130 mm x $320 \mathrm{~mm}$ x $120 \mathrm{~mm}$ ) was used for treatments with sterilant solution. Sterilization was undertaken for 6 min using $0.1 \%$ (w/v) $\mathrm{HgCl}_{2}$. Explants were transferred to a separate vessel for the washing phase in three changes of sterile distilled water.

Antioxidant treatment: The extracted buds were placed in petri dishes containing an antioxidant wash of $0.125 \%$ potassium citrate: citrate (K-C: $\mathrm{C}$ in a ratio of $4: 1 \mathrm{w} / \mathrm{w})$ solution. A concentrated stock of the antioxidant wash was filter sterilized (with $0.22-\mu \mathrm{M}$ disposable filter) and frozen in $10 \mathrm{~mL}$ units until required. The concentrate was later thawed and further diluted with SDW to give the final $0.125 \%$ concentration. Petri dishes (90 mm x $14 \mathrm{~mm}$ ) were filled with sufficient antioxidant solution to fully cover the explants. Peduncle sections were cut into discs under the antioxidant solution to minimize browning during initial preparation. Each explant was placed in a test tube containing $20 \mathrm{~mL}$ of media after five $\mathrm{min}$ in the antioxidant treatment.

Growth responses: After antioxidant treatment the floral bud explants of banana were cultured on MS solid medium supplemented with cytokinins, auxins and coconut water for initiating vegetative growth. After 3 weeks of culture compact, white/greenish white callus was formed more or less at all treatments. All were again subcultured at same medium and after another 30-35 days at a specific concentration some callus showed embryogenic structure but others remained unchanged. These were observed at the conclusion of this research and were not able to be further analyzed.

\section{RESULTS AND DISCUSSION}

The experiment was conducted at Plant Biotechnology Laboratory of Khulna University, Bangladesh during January to November 2005. One indigenous banana plant (Musa spp. cv. Kanthali) of Bangladesh was studied in order to establish suitable protocols for in vitro plant regeneration. In the present investigation in vitro growth responses of floral bud apices from mature plants was studied for large scale plant propagation.

For culture initiation all the experimental explants were cultured on MS medium supplemented with different concentrations of cytokinins and auxins for promoting the morphogenic responses. The results of the experiment are described as follows:

Sterilization procedure for explant: To overcome contamination problem surface sterilization of explants was done with $0.1 \%(\mathrm{w} / \mathrm{v}) \mathrm{HgCl}_{2}$ for different durations to assess the contamination percentages and viability of the explants used for in vitro culture.

Contamination free cultures with elegant survivability $(100 \%)$ were achieved by treating the explants with $0.1 \% \mathrm{HgCl}_{2}$ for 6 min (Table 1).

Techniques applied for reducing phenolic compound secretion of explants: One of the most common problems associated with the in vitro establishment of many monocotyledonous and woody species is the deleterious effects of oxidized phenols ${ }^{[18,19]}$. The results of the detection of phenolic compounds experiment (Table 2-4) clearly indicate that Musa spp. cv. Kanthali has phenolic compounds present in inflorescence tissue. This experiment provides a simple technique for detecting the presence of phenolic compounds in banana inflorescence tissue. This procedure assists in early detection of phenols ${ }^{[20]}$ and assists in preparation of explant source material to reduce injury associated with phenolic oxidation. George ${ }^{[21]}$ describes an antioxidant as an electron donor (reducing agent) which 
Am. J. Biochem. And Biotech., 2 (3): 97-104, 2006

Table 1: Standardization of $\mathrm{HgCl}_{2}$ treatment period for surface sterilization of the explants

\begin{tabular}{|c|c|c|c|c|c|c|c|}
\hline \multirow{2}{*}{$\begin{array}{l}\text { Treatment duration (min.) with } \\
0.1 \% \mathrm{HgCl}_{2}\end{array}$} & \multirow{2}{*}{$\begin{array}{l}\text { Number of } \\
\text { explants }\end{array}$} & \multicolumn{5}{|c|}{ Rate of contamination (after days of treatment) } & \multirow{2}{*}{$\begin{array}{c}\text { Percentage of } \\
\text { contamination free } \\
\text { explants after } 15 \text { days }\end{array}$} \\
\hline & & 3 & 6 & 9 & 12 & 15 & \\
\hline 1 & 10 & - & 5 & 7 & 8 & 10 & - \\
\hline 2 & 10 & 1 & 4 & 6 & 6 & 7 & 30 \\
\hline 4 & 10 & - & 1 & 1 & 3 & 3 & 80 \\
\hline 6 & 10 & - & - & - & - & - & 100 \\
\hline 8 & 10 & - & - & - & - & - & $100 *$ \\
\hline 10 & 10 & - & - & - & - & - & $100 * *$ \\
\hline 12 & 10 & - & - & - & - & - & $100 * * *$ \\
\hline 15 & 10 & - & - & - & - & - & $100 * * * *$ \\
\hline indicates no contami & & & & & & & \\
\hline$(*=5-25 \% ; * *=26-50 \% ; * * *$ & & & & & & & \\
\hline
\end{tabular}

Table 2: Antioxidant treatments

\begin{tabular}{llc}
\hline Treatment Number & \multicolumn{1}{c}{ Treatment } & Volume of antioxidant treatment (ml) \\
\hline 1 & Exposed to air, cut on wet filter paper & 0 \\
2 & Cut in petri dish plus $\mathrm{H}_{2} \mathrm{O}(\mathrm{SDW})$ & 100 \\
3 & Cut in petri dish plus $\mathrm{H}_{2} \mathrm{O}($ reverse osmosis $)$ & 100 \\
4 & Cut in K-C: $\mathrm{C}(0.125 \% \mathrm{w} / \mathrm{v})$ & 100 \\
5 & Cut in K-C: $\mathrm{C}(0.125 \% \mathrm{w} / \mathrm{v})+\mathrm{L}$-cysteine & 100 \\
6 & Cut in K-C:C $(0.125 \% \mathrm{w} / \mathrm{v})+$ L-cysteine + Ascorbic acid & 100 \\
\hline
\end{tabular}

Table 3: egree of tissue discoloration after incubation in $\mathrm{NaOH}$ solutions for Musa spp. cv. Kanthali

\begin{tabular}{|c|c|c|c|c|c|}
\hline Section type & $\begin{array}{l}\begin{array}{l}\text { Control } \\
\text { (SDW) }\end{array} \\
\end{array}$ & $\begin{array}{c}0.001 \mathrm{M} \\
\mathrm{NaOH}\end{array}$ & $\begin{array}{l}0.01 \mathrm{M} \\
\mathrm{NaOH}\end{array}$ & $\begin{array}{c}0.1 \mathrm{M} \\
\mathrm{NaOH}\end{array}$ & $\begin{array}{c}1 \mathrm{M} \\
\mathrm{NaOH}\end{array}$ \\
\hline Peduncle sections & $\mathrm{O}$ & $\mathrm{O}$ & + & ++ & +++ \\
\hline Pedicel sections & $\mathrm{O}$ & $\mathrm{O}$ & + & ++ & +++ \\
\hline Bract tissue & $\mathrm{O}$ & $\mathrm{O}$ & + & ++ & ++ \\
\hline
\end{tabular}

\begin{tabular}{ll}
\hline "O" & no discoloration \\
"+" & low discoloration \\
"++" & medium discoloration \\
"+++" & high (darkly stained)
\end{tabular}

inhibits the oxidation of labile substrates. The antioxidant compounds utilized in the experimental work in this chapter were selected because they have been used successfully in the past to delay browning in other arborescent monocotyledonous species $^{[18]}$. George $^{[21]}$ details the use of citric acid and ascorbic acid combinations to delay browning. The successful prevention of browning in explants of Musa textilis by using a mixture of ascorbic acid, citric acid and cysteine are reported by Mante and Tepper ${ }^{[22]}$. The behavior of the citrate in citric acid works as a chelating agent bonding to ions responsible for activating polyphenol oxidative enzymes ${ }^{[21]}$. Ascorbate behaves as a reducing agent and is converted to dehydro-ascorbic acid ${ }^{[20]}$. Ascorbate is able to scavenge oxygen radicals produced when tissue is damaged and therefore cells are protected from oxidative injury. Oxygen radicals are attributed to exacerbating oxidative injury. Antioxidants containing citrate and ascorbate reduce browning of tissue by detoxifying these free radicals. The results provide evidence that $\mathrm{K}-\mathrm{C}$ : $\mathrm{C}$ combination is a useful antioxidant for explant preparation for Musa spp. cv. Kanthali.

Musa spp. cv. Kanthali stems are susceptible to tissue browning and elimination or minimization of this process is an essential prerequisite to successful culture establishment. Therefore identification of a suitable treatment to minimize tissue browning in the explant source material of Musa spp. cv. Kanthali will be the focus of this chapter. The specific aim of this component of the study was to:

* Research methods for reducing phenolic induced injury in Musa spp. cv. Kanthali during explant preparation with particular emphasis on the use of appropriate antioxidant treatments.

* Detection of phenolic compounds using sodium hydroxide $(\mathrm{NaOH})$

* Detection of phenolic leakage was tested in the study plant Musa spp. cv. Kanthali. Flowering stems of Musa spp. cv. Kanthali were collected from a village named Amtola in Batiaghata Thana, Khulna for assessment. Concentrations of sodium hydroxide $(\mathrm{NaOH})$ were made at rates $1 \mathrm{M}, 0.1 \mathrm{M}, 0.01 \mathrm{M}$ and $0.001 \mathrm{M}$ to treat the various plant tissues. $\mathrm{NaOH}$ oxidizes phenols which causes darkening of affected or damaged tissue ${ }^{[20]}$. Peduncle sections and pedicel slices of Musa spp. cv. Kanthali were cut in $2 \mathrm{~mm}$ thick discs and submerged in petri dishes containing the concentrations of $\mathrm{NaOH}$ for $5 \mathrm{~min}$. Similarly, bract tissue was cut into squares approximately 15 $\mathrm{mm} \times 15 \mathrm{~mm}$ and also placed in the $\mathrm{NaOH}$ solutions. Observations were made of any browning on the surface or cut edges of the various plant tissue to assess if phenolic leakage had occurred. 
Am. J. Biochem. And Biotech., 2 (3): 97-104, 2006

Table 4: Relative browning of disc sections of Musa spp. cv. Kanthali treated with antioxidants over a two hour period Time ( $\mathrm{min}) \quad$ Treatment Number

\begin{tabular}{|c|c|c|c|c|c|c|}
\hline & 1 & 2 & 3 & 4 & 5 & 6 \\
\hline$\overline{0}$ & +++ & ++ & + & $\mathrm{O}$ & $\mathrm{O}$ & $\mathrm{O}$ \\
\hline 6 & +++ & +++ & ++ & $\mathrm{O}$ & + & $\mathrm{O}$ \\
\hline 30 & +++ & +++ & +++ & $\mathrm{O}$ & + & + \\
\hline 60 & +++ & +++ & +++ & $\mathrm{O}$ & ++ & ++ \\
\hline 120 & +++ & +++ & +++ & $\mathrm{O}$ & +++ & +++ \\
\hline
\end{tabular}

"O" no oxidation

"+" low oxidation

"+ +" medium oxidation

" +++ " high oxidation

Treatment numbers:

$1 \rightarrow$ Exposed to air, cut on wet filter paper.

$2 \rightarrow$ Cut in petri dish plus $\mathrm{H}_{2} \mathrm{O}$ (SDW)

$3 \rightarrow$ Cut in petri dish plus $\mathrm{H}_{2} \mathrm{O}$

$4 \rightarrow$ Cut in K-C: C $(0.125 \%$ w/v $)$

$5 \rightarrow$ Cut in K-C: C $(0.125 \%$ w/v $)+$ L-cysteine

$6 \rightarrow$ Cut in K-C: C $(0.125 \% \mathrm{w} / \mathrm{v})+$ L-cysteine + ascorbic acid

Table 5: Effect of different concentrations of BA in combination with Kn, IAA and 15\% CW for callus induction from banana floral bud explant. There were 10 explants for each treatment and data were taken after 3 weeks of culture

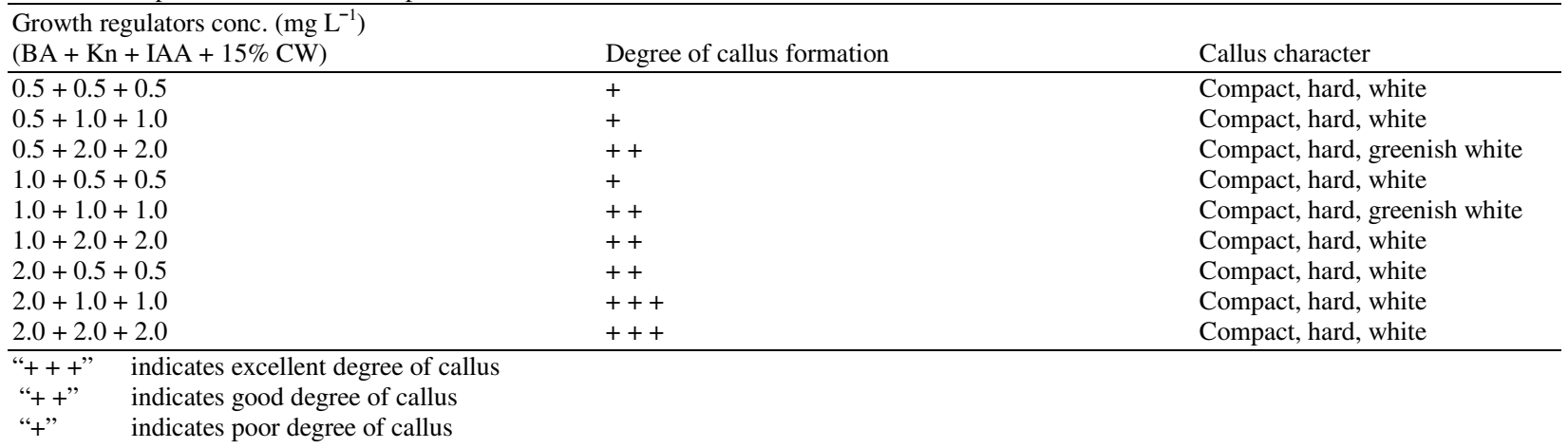

Table 6: Effect of different concentrations of BA in combination with Kn, IAA and 15\% CW for callus induction from banana floral bud explant. There were 10 explants for each treatment and data were taken after 3 weeks of culture

Growth regulators conc. $\left(\mathrm{mg} \mathrm{L}^{-1}\right)$

$(\mathrm{BA}+\mathrm{Kn}+\mathrm{IBA}+15 \% \mathrm{CW})$

Degree of callus formation

Callus character

$0.5+0.5+0.5$

$0.5+1.0+1.0$

$0.5+2.0+2.0$

$1.0+0.5+0.5$

$1.0+1.0+1.0$

$1.0+2.0+2.0$

$2.0+0.5+0.5$

$2.0+1.0+1.0$

$2.0+2.0+2.0$

" +++ indicates excellent degree of callus

" ++ indicates good degree of callus

" + indicates poor degree of callus

Compact, hard, white

Compact, hard, white

Compact, hard, greenish white

Compact, hard, white

Compact, hard, greenish white

Compact, hard, white

Compact, hard, white

Compact, hard, white

Compact, hard, greenish white
Antioxidant experiment: Pedicel and peduncle disc sections from Musa spp. cv. Kanthali were collected from a mature flower stem and treated with various antioxidant solutions. Disc sections were selected as they have a large surface area and have been shown to be prone to oxidation (Table 2).

A stock solution of potassium citrate and citrate (K-C: C) was made up using $1 \mathrm{~g} \mathrm{~K}-\mathrm{C}$ and $0.25 \mathrm{~g}$ citrate and dissolved in $10 \mathrm{~mL}$ of SDW. The concentrate was then diluted and used at a final concentration of $0.125 \%$. For treatments 5 and $60.02 \mathrm{~g} \mathrm{~L}^{-1} \mathrm{~L}$-cysteine $\mathrm{HCl}$ was added to the $0.125 \%$ solution of $\mathrm{K}-\mathrm{C}$ : $\mathrm{C}$ and $0.25 \mathrm{~g} \mathrm{~L}^{-1}$ ascorbic acid was added to treatment 6 . One hundred milliliters of the various solutions were used to fully cover the disc sections with the control treatment cut on filter paper and exposed to air. All other material was cut under the various treatments to avoid exposure to the air. The prepared disc sections were placed onto water agar petri dishes and results were recorded at time at intervals of $0,7,30,60$ and $120 \mathrm{~min}$. Observations of the extent of browning were recorded.

Detection of phenolic compounds using sodium hydroxide (NaOH): Pedicel and peduncle sections produced a large degree of discoloration after having been sliced into discs and placed in the $\mathrm{NaOH}$. The 
bract tissue of Musa spp. cv. Kanthali developed a distinct green/brown line, approximately $2 \mathrm{~mm}$ wide around the cut edges (Table 3).

Antioxidant experiment: All cut surfaces in the control appeared to oxidize rapidly once exposed to air as evidenced by tissue browning. Subsequently all other tissues were prepared under each of the antioxidant treatments. Pedicel sections showed similar rates of browning to excised flower bud material when exposed to air without antioxidant treatment. Treatments 4,5 and 6 initially reduced browning of the disc sections and after $2 \mathrm{hrs}$, treatment 4 (K-C: C) was visually better than the other 2 antioxidant treatments (Table 4).

Potassium citrate-citrate combinations as antioxidant treatments for excised tissue: All tissues initiated into culture were treated with the K-C: C treatment as it proved to be the best treatment type from experimental results. The antioxidant treatment reduced browning in all tissue types after $24 \mathrm{hrs}$ in culture. The cut surfaces and any damaged areas of untreated tissue (particularly peduncle sections) turned brown within 15 min after the excision. These explants continued to oxidize under culture conditions and were completely brown after $1 \mathrm{hr}$ and were subsequently discarded.

After 3 weeks of culture the phenolic leakage in treated tissues was minimized and in most cases controlled. Many of the explants had remained pale while others had started showing signs of greening. Some minor staining of the media was evident in some explant tissues predominantly in peduncle sections. The results from this study indicate the browning phenomenon in Musa spp. cv. Kanthali tissue can be greatly reduced by pre-soaking of explants in antioxidant solution of $0.125 \%(\mathrm{w} / \mathrm{v})$ potassium citrate and citrate prior to culture. Also, incubation in the dark for the first 1 week may arrest the rate of tissue browning by slowing the enzymatic activity responsible for tissue oxidation. Frequent subculturing to fresh medium may also assist so that toxic phenolic compounds do not hinder the activity of plant growth regulators on tissues. The combined effects of the treatments outlined above proved beneficial to explant survival in vitro of Musa spp. cv. Kanthali inflorescence tissue (Fig. 1).

Organ formation from floral bud explants: Floral bud apices of banana (Musa spp. cv. Kanthali) were isolated aseptically. Then after successful sterilization and antioxidant treatment they were cultured on MS medium supplemented with different cytokinins, auxins and coconut water for initiating vegetative growth (Table 5).

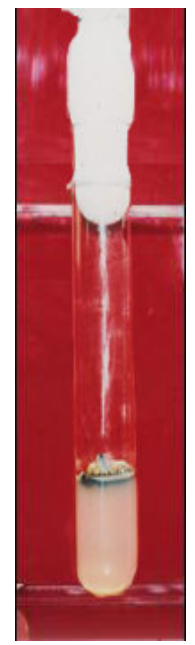

A

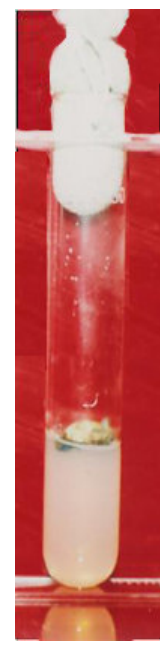

B
Fig. 1: Comparison between untreated (A) and treated (B) floral bud apex explants for excessive phenolic compound secretion

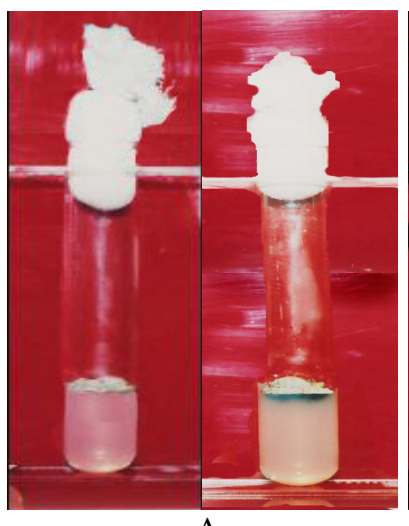

A

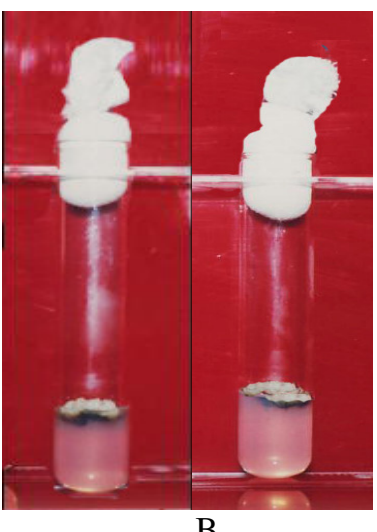

B
Fig. 2: Excellent degree of callus formation from banana floral bud explants on MS medium supplement with $2.0 \mathrm{mg} \mathrm{L}^{-1} \mathrm{BA}+1.0 \mathrm{mg} \mathrm{L}^{-1}$ $\mathrm{Kn}+1.0 \mathrm{mg} \mathrm{L}{ }^{-1} \mathrm{IAA}+15 \% \mathrm{CW}$ (A) and 2.0 $\mathrm{mg} / \mathrm{l} \mathrm{BA}+2.0 \mathrm{mg} \mathrm{L}^{-1} \mathrm{Kn}+2.0 \mathrm{mg} \mathrm{L}^{-1} \mathrm{IAA}+$ $15 \% \mathrm{CW}(\mathrm{B})$

Effect of different concentrations and combinations of BA, Kn, IAA and $15 \% \mathrm{CW}$ for callus induction: Floral bud explants of banana were cultured on MS solid medium supplemented with different concentrations and combinations of BA, Kn, IAA and $15 \%$ coconut water for initiating vegetative growth. After 3 weeks, cultures showed enlargement of the floral primordial and compact, whitish/greenish white callus was formed more or less at all treatments. But at $\mathrm{MS}+2.0 \mathrm{mg} \mathrm{L}^{-1} \mathrm{BA}+1.0 \mathrm{mg} \mathrm{L}^{-1} \mathrm{Kn}+1.0 \mathrm{mg} \mathrm{L}^{-1}$ $\mathrm{IAA}+15 \% \mathrm{CW}$ and $\mathrm{MS}+2.0 \mathrm{mg} \mathrm{L}^{-1} \mathrm{BA}+2.0 \mathrm{mg} \mathrm{L}^{-1}$ $\mathrm{Kn}+2.0 \mathrm{mg} \mathrm{L}^{-1} \mathrm{IAA}+15 \% \mathrm{CW}$ excellent degree of callus was formed. And very poor degree of callus was formed at $\mathrm{MS}+0.5 \mathrm{mg} \mathrm{L}^{-1} \mathrm{BA}+0.5 \mathrm{mg} \mathrm{L}^{-1} \mathrm{Kn}+0.5$ $\mathrm{mg} \mathrm{L}^{-1} \mathrm{IAA}+15 \% \mathrm{CW}$ and $\mathrm{MS}+1.0 \mathrm{mg} \mathrm{L}^{-1} \mathrm{BA}+0.5$ $\mathrm{mg} \mathrm{L}{ }^{-1} \mathrm{Kn}+0.5 \mathrm{mg} \mathrm{L}^{-1} \mathrm{IAA}+15 \% \mathrm{CW}$. 
Am. J. Biochem. And Biotech., 2 (3): 97-104, 2006

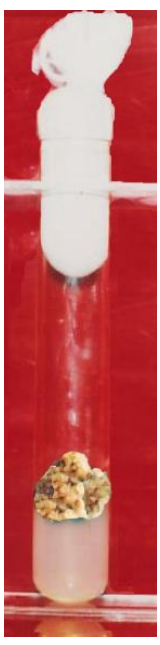

Fig. 3: Embryogenic callus formation from floral bud explant of banana on $\mathrm{MS}+2.0 \mathrm{mg} \mathrm{L}^{-1} \mathrm{BA}+$ $2.0 \mathrm{mg} \mathrm{L}^{-1} \mathrm{Kn}+2.0 \mathrm{mg} \mathrm{L}^{-1} \mathrm{IAA}+15 \% \mathrm{CW}$

Effect of different concentrations and combinations of $\mathrm{BA}, \mathrm{Kn}, \mathrm{IBA}$ and $15 \% \mathrm{CW}$ for callus induction: The floral bud explants of banana were again cultured on MS solid medium supplemented with different concentrations and combinations of BA, Kn, IBA and $15 \%$ coconut water for observation of their vegetative growth. After 3 weeks, cultures showed enlargement of the floral primordial and compact, whitish/greenish white callus was formed more or less at all treatments just like previous treatment. But at $\mathrm{MS}+2.0 \mathrm{mg} \mathrm{L}^{-1}$ $\mathrm{BA}+0.5 \mathrm{mg} \mathrm{L}^{-1} \mathrm{Kn}+0.5 \mathrm{mg} \mathrm{L}^{-1} \mathrm{IBA}+15 \% \mathrm{CW}$ and $\mathrm{MS}+2.0 \mathrm{mg} \mathrm{L}^{-1} \mathrm{BA}+1.0 \mathrm{mg} \mathrm{L}^{-1} \mathrm{Kn}+1.0 \mathrm{mg} \mathrm{L}^{-1}$ IBA $+15 \% \mathrm{CW}$ excellent degree of callus was formed (Table 6).

Subculture for somatic embryo like structure development: All the callus were again subcultured at same medium and after another 30-35 days at 2.0 $\mathrm{mg} \mathrm{L}^{-1} \mathrm{BA}+2.0 \mathrm{mg} \mathrm{L}^{-1} \mathrm{Kn}+2.0 \mathrm{mg} \mathrm{L}^{-1} \mathrm{IAA}+15 \%$ $\mathrm{CW}$ some callus showed embryogenic structure. The embryogenic callus showed several developed embryos on the surface. However, conversion of these embryos into plants did not occur, probably due to a lack of development of the shoot apical meristem. Similar results were obtained by Lee et al. ${ }^{[23]}$ and Grapin et $a l .{ }^{[24]}$ with banana somatic embryos and Nickle and Yeung ${ }^{[25]}$ with Daucus carota L (Fig. 2).

More detailed studies should be developed aiming to obtain banana somatic embryos of higher quality, which can efficiently convert into plants. Somatic embryo quality can be improved with optimization of parameters like the type and concentration of plant growth regulators, time in induction medium and maturation treatments. Somatic embryo quality is essential for high somatic embryo conversion rates (Fig. 3).

\section{CONCLUSION}

This study examined the application of micropropagation protocols to assist germplasm conservation of a traditional cultivar table banana [Musa spp. cv. Kanthali (Genome, AAB)] of Bangladesh. This has implications for commercial explant production in large scale as it generally produce 5-6 suckers from a mature mother plant per year. For in vitro propagation of banana, bacterial contamination is a great problem. So, the aim was to investigate the floral bud apices as an alternative explant source material because it favors minimal contamination rates compared to other tissues. Key factors investigated in this study includes sterilization technique to establish contamination free culture, control of phenolic exudates in explant preparation and the selection of appropriate growth regulator levels to achieve successful in vitro regeneration.

One of the most commonly encountered problems in in vitro culture establishment is the contamination by microbial contaminants. One hundred percent contamination free culture was established by soaking the floral bud explants in $0.1 \% \mathrm{HgCl}_{2}$ for $6 \mathrm{~min}$ followed by several washes in sterile water obviated the need to develop extensive and complicated surface sterilization protocols.

This study found that inflorescence tissues of experimental plant were high in phenolic compounds. The oxidation of tissues was severe and proved deleterious to all tissues in the initial stages of explant preparation. So, for reduction of phenolic compounds explants were pre-soaked in antioxidant solution of $0.125 \%(\mathrm{w} / \mathrm{v})$ potassium citrate: citrate. Then they were placed in dark for 1 week so that rate of tissue browning was arrested. The effect of the treatments outlined above proved beneficial to explant survival in vitro of Musa spp. cv. Kanthali inflorescence tissue.

For successful explant establishment, a wide range of cytokinin and auxin combinations were investigated. The floral bud apices were cultured for 3 weeks on MS basal medium supplemented with various concentrations and combinations of cytokinins, auxin and additives. Hard, compact, white/greenish white callus was formed in different amounts at all concentrations. All were again subcultured at same medium and after another $30-35$ days at $2.0 \mathrm{mg} \mathrm{L}^{-1} \mathrm{BA}$ $+2.0 \mathrm{mg} \mathrm{L}^{-1} \mathrm{Kn}+2.0 \mathrm{mg} \mathrm{L}^{-1} \mathrm{IAA}+15 \% \mathrm{CW}$ some callus showed embryogenic structure. Present investigations have thus shown that the economically valuable Musa spp. cv. Kanthali could be regenerated in vitro via somatic embryogenesis. The protocol developed will be useful for rapid in vitro propagation of the species and also for the subsequent genetic manipulation studies. 


\section{ACKNOWLEDGMENTS}

First of all we would like to express our deepest gratitude for the personnel of Plant Biotechnology Laboratory of Khulna University, Khulna-9208, Bangladesh for their invaluable support and instructions they all gave us during this experiment. We would also like to thank Khulna University Research Cell for financing of this research.

\begin{tabular}{ll} 
Abbreviations & \\
\hline$\mu \mathrm{M}$ & Micromole \\
$\mathrm{BA}$ & 6-Benzyl adenine \\
$\mathrm{CW}$ & Coconut water \\
$\mathrm{IAA}$ & Indole-3-acetic acid \\
$\mathrm{IBA}$ & Indole-3-butyric acid \\
$\mathrm{Kn}$ & Kinetin (6-furfuryl amino purine) \\
$\mathrm{NAA}$ & $\alpha$-Napthaleneacetic acid \\
$\mathrm{p}^{\mathrm{H}}$ & Negative logarithm of Hydrogen ion $\left(\mathrm{H}^{+}\right)$ \\
$\mathrm{v} / \mathrm{v}$ & Volume per volume \\
$\mathrm{w} / \mathrm{v}$ & Weight per volume \\
\hline
\end{tabular}

\section{REFERENCES}

1. Vuylsteke, D.R., 1989. Shoot-tip culture for the propagation, conservation and exchange of Musa Germplasm. Practical manuals for handling crop germplasm in vitro. International Board for Plant Genetic Resources, Rome.

2. Chattopadhyay, P.K. and M.A. Hasan, 2000. Banana: Improvement, Production and Utilization. In: Singh, H.P. and Chadha, K.L. Eds. Current status of banana production and utilization in West Bengal. New Delhi, IBH Publishing Co Pvt Ltd, pp: 70-74.

3. Vuylsteke, D., 1998. Field Performance of Banana Micropropagules and Somaclones. In: Jain, S.M., Brar, D.S. and Ahloowalia B.S. Eds. Somaclonal Variation and Induced Mutation in Crop Improvement. Dordrecht, Kluwer, Academic Publishers, pp: 219-231.

4. Israeli, Y., E. Lahav and O. Reuveni, 1995. In vitro Culture of Bananas. In: Gowen, S. Ed. Bananas and Plantains. London, Chapman \& Hall Publishers, pp: 147-178.

5. Cronauer, S.S. and A.D. Krikorian, 1984. Rapid multiplication of bananas and plantains by in vitro. Horticult. Sci., 19: 234-235.

6. Doreswamy, R. and L. Sahijram, 1989. Micropropagation of banana from male floral apices culture in vitro. Sci. Horticult., 40: 181-188.

7. Gupta, P.P., 1986. Eradication of mosaic disease and rapid clonal multiplication of bananas and plantains through meristem-tip culture. Plant Cell, Tissue and Organ Culture, 6: 33-39.
8. Novak, F.J., R. AFZA, M. Van Duren, M. PereaDallos, B.V. Conger and T. Xiolang, 1989. Somatic embryogenesis and plant regeneration in suspension cultures of dessert (AA, AAA) and cooking (AAB) bananas. Bio/Technology, 7: 154159.

9. Cotê, F.X., R. Domergue, S. Monmarson, J. Schwendiman, C. Teisson and J.V. Escalant, 1996. Embryogenic cell suspension from the male flower of Musa AAA cv. Grand Nain. Physiol. Plant., 97: 285-290.

10. Azad, M.A.K. and M.N. Amin, 2001. Rapid clonal propagation of Banana (Musa spp.) using in vitro culture of floral bud apex. Plant Tissue Culture, 11: 1-9.

11. Wildi, E., W. Schaffner and K.B. Buter, 1998. In vitro propagation of Petasites hybridus (Asteraceae) from leaf and petiole explants and from inflorescence buds. Plant Cell Report, 18: 336-340.

12. Amomarco, J.B. and M.R. Ibanez, 1998. Micropropagation of Limonium cavanillesii Erben, a threatened statice, from inflorescence stems. Plant Growth Regulation, 24: 49-54.

13. Holme, I.B. and K.K. Petersen, 1996. Callus induction and plant regeneration from different explant types of Miscanthus $x$ ogiformis Honda 'Giganteus'. Plant Cell, Tissue and Organ Culture, 45: 43-52.

14. Bunn, E. and K.W. Dixon, 1996. In vitro propagation methods for Blandfordia grandiflora, Hibbertia miniata, Newcastelia chrysophylla and Eucalyptus graniticola. In: Proc. Intl. Assoc. for Plant Tissue Culture-Australian Branch $5^{\text {th }}$ Meeting. Abstracts, pp: 157-163.

15. Loutfi, K. and H. Chlyah, 1998. Vegetative multiplication of date palms from in vitro cultured inflorescences: effect of some growth regulator combinations and organogenetic potential of various cultivars. Agronomie, 18: 573-580.

16. Hadiuzzaman, S., U. Habiba, S. Reza, M.L. Saha and M.R. Khan, 2001. Development of a sustainable protocol for contamination free culture of table bananas and identification of associated endogenous bacteria. In: $4^{\text {th }}$ Intl. Plant Tissue Culture Conf., ( $1^{\text {st }}-3^{\text {rd }}$ November, 2001, Dhaka, Bangladesh). Abstracts, pp: 24.

17. Taji, A.M. and R.R. Williams, 1996. Overview of Plant Tissue Culture. In: Taji, A.M. and Williams, R.R. Eds. Tissue Culture of Australian Plants: Past, Present and Future. Armidale, Australia, University of New England Press, pp: 1-15.

18. Khatri, A., I.A. Khan, S.H. Siddiqui, M. Ahmed and K.A. Siddiqui, 1997. In vitro culture of indigenous and exotic banana clone for maximizing multiplication. Pak. J. Bot., 29: 143150. 
19. Zweldu, T. and P. Ludders, 1998. Preliminary tissue culture investigation in Ensete (Ensete spp.). J. Appl. Bot., 72: 25-27.

20. Panaia, M., 1998. Rescuing Symonanthes bancroftii (Solanaceae), a Western Australian native species from extinction through in vitro micropropagation. Honours Thesis, University of Western Australia.

21. George, E.F., 1996. Plant Propagation by Tissue Culture, Parts 1 \& 2. Edington, Wilts, Exegetics Ltd., pp: 131-134.

22. Mante, S. and H.B. Tepper, 1983. Production of Musa textiles cv. Nee plants from apical meristem slices in vitro. Plant Cell, Tissue and Organ Culture, 2: 151-159.
23. Lee, K.S., F.J. Zapata-Arias, H. Brunnel and R. AFZA, 1997. Histology of somatic embryo initiation and organogenesis from rhizome explants of Musa spp. Plant Cell, Tissue and Organ Culture, 51: 1-8.

24. Grapin, A., J. Schwendiman and C. Teisson, 1996. Somatic embryogenesis in plantain bananas. In vitro Cell. Develop. Biol.-Plant, 32: 66-71.

25. Nickle, T.C. and E.C. Yeung, 1993. Failure to establish a functional shoot meristem may be a cause of conversion failure in somatic embryos of Daucus carota (Apiaceae). Am. J. Bot., 80: 12841291. 